\title{
Behavior of swine hosted in facilities with different construction typologies
}

Daiane Cecchin - Alessandro Torres Campos - Pedro Ivo Sodré Amaral •

Francine Aparecida Sousa - Patrícia Ferreira Ponciano Ferraz •

Cristina Moll Hüther - Carlos Rodrigues Pereira - Vasco Manuel Fitas da Cruz

D Cecchin (Corresponding author) - CR Pereira

Department of Agricultural Engineering and Environment Universidade Federal Fluminense (UFF), Niterói, RJ, Brazil. email: daianececchin@yahoo.com.br

\section{AT Campos - PFP Ferraz}

Universidade Federal de Lavras (UFLA), Lavras, MG, Brazil.

\section{PIS Amaral}

Universidade José do Rosário Vellano (UNIFENAS), Alfenas, MG, Brazil.

\section{FA Sousa}

SEMAG/Aracruz, ES, Brazil.

\section{Hüther}

Universidade Federal do Rio de Janeiro (UFRJ), Rio de Janeiro, RJ, Brazil.

\section{VMF Cruz}

Universidade de Évora (UE), Portugal.

Received: March 08, 2018 - Revised: July 11, 2018 - Accepted: August 06, 2018

\begin{abstract}
The aim of this study was to analyze the behavior of pigs housed in facilities with different building typologies in terms of the floor and partitions. Two treatments were compared: a pen containing an area with a depth of water, and a pen floor with leaked on the sides. Data on swine behavior were collected over seven days, and the pigs' positions (standing, sitting, and lying down) and activities (eating, drinking, digging, interacting, walking and idling) were observed for five animals in each pen. Data were collected via visual measurement every 10 minutes and an ethogram was constructed. Measurements of environmental data were taken (dry bulb temperature, globe temperature and relative humidity), and were used to calculate the black globe temperature and humidity index. Although the pens showed differences in terms of the dry bulb temperature, this temperature can be considered thermoneutral for creation in the growth and termination phases. Animals housed in the pens with an area of water depth stood for longer, possibly due to the environmental enrichment caused by the presence of the water slide.
\end{abstract}

Keywords: animal welfare, growth and finishing, rural buildings

\section{Introduction}

Brazilian pig farms have evolved a great deal in recent years following research carried out in the areas of production, nutrition, genetics, health and environmental systems; however, more attention to animal welfare is still necessary (Veloni et al 2013). Animal welfare, environmental issues and food safety are currently considered to be the three biggest challenges in the pig sector. In view of this, there is significant concern regarding the influence of the environment on the comfort, welfare and performance of the animals (Ferreira et al 2015).

In this context, the evaluation of animal welfare on the farm can involve aspects related to the management, environment and facilities, for example the distribution of food, room for movement, rest, interaction between animals, air temperature, relative humidity, ventilation, light, available space and type of flooring (Anil et al 2002). According to Maia et al (2013), the provision of an adequate breeding environment can allow more positive welfare to be created, which may favor better productive performance in these animals.

Pigs subjected to thermal conditions that are outside their comfort zones may show altered physiological and behavioral responses, which may consequently cause losses related to the productive responses of these animals (Kiefer et al 2009, Kiefer et al 2010). The initial response of a pig subjected to an increase in air temperature is a change in behavior (Huynh et al 2005). According to Machado, Filho and Hötzel (2000), factors causing stress can lead the pig to change its natural behavior to stereotypies. Kittawornrat and Zimmerman (2011) find that stress is a routine aspect of life for pigs and occurs in the context of social dynamics (feeding and aggressive interactions) and the environment (heat, cold and new environmental situations).

The objective of the present study is to analyze the behavior of growing and finishing pigs housed in facilities with different constructive typologies.

\section{Materials and Methods}


The study was carried out in a commercial swine farm ( $21^{\circ} 11^{\prime} 37^{\prime}$ ' S; $45^{\circ} 02^{\prime} 49^{\prime}$ ' $\mathrm{W}$; $918 \mathrm{~m}$ ), in the municipality of Lavras-MG, Brazil. The climate of the region, according to Köppen's classification, is Cwa, i.e. rainy, temperate (mesothermal) and subtropical, with a dry winter and rainy summer.

The raising system evaluated here involved intensive confinement, and the animals did not have access to the outside of the facilities.

The animals were housed in two pens of different construction typologies in relation to the floor and partitions: a pen with a water depth (WDP) and pens with partially slotted floors at the sides (SLS). The average weight of the piglets housed in each typology were $28.69 \mathrm{~kg}$ and $28.75 \mathrm{~kg}$, respectively. The animals remained in the pens during the growing and finishing stages, reaching final mean weights of $83.47 \mathrm{~kg}$ (WDP pen) and $85.47 \mathrm{~kg}$ (SLS pen).

The animals were housed in masonry barns covered with fiber-cement roofing, with supporting structures of reinforced concrete, concrete flooring, and an east-west orientation. Each pen was equipped with two automatic feeders and four nipple drinkers, with a total area of $72 \mathrm{~m}^{2}(8$ $\mathrm{x} 9 \mathrm{~m}$ ) and ceiling height of $3 \mathrm{~m}$, containing 72 animals each. On one of its sides, the WDP pen had an indentation in the concrete floor ( $1 \mathrm{~m}$ wide and $10 \mathrm{~cm}$ deep) filled with water; this pen was fenced with masonry dividers made of ceramic bricks (with a height of $60 \mathrm{~cm}$ ) covered with a layer of concrete render and painted in white. The SLS pen had lateral brick masonry partitions (60 $\mathrm{cm}$ in height) covered with a layer of plaster painted in white, and a concrete floor and with leaked in the sides.

Over seven days, data on the pigs' behavior were collected in an ethogram (Table 1) that included posture (standing, sitting, and lying down) and activities (eating, drinking, digging, interacting, walking and idling) (adapted Massari et al 2015). The data were collected by means of a visual check every 10 minutes (from 07:00 to 17:00 hours). The behavior of five animals in each pen was evaluated. Before starting the experiment, these animals were identified by ear tags; the day before the behavioral data began to be collected, these animals received markings on their backs using non-toxic paints in different colors, to allow easier identification of each animal. Evaluations were conducted simultaneously in the two pens, with one person responsible for the bay over the entire evaluation period.

Data relative to the ambient thermal comfort in the pens and outside were automatically collected using data loggers (Hobo, model U12-013) with an accuracy of $\pm 0.5 \mathrm{oC}$. These devices recorded the dry bulb temperature $(\mathrm{Tdb})$, relative air humidity $(\mathrm{RH})$ and black globe temperature (Tbg) at intervals of five minutes. The air velocity (Vair) was recorded at 9:00 a.m., 12:00 p.m., and 3:00 p.m. on the evaluation days, using a digital propeller anemometer (ICEL
Manaus ${ }^{\circledR}$ brand, model AN-3090) with a precision of $\pm 3.0 \%$. The data loggers were positioned inside the facilities at a height of $1.20 \mathrm{~m}$ from the floor, as described in Sampaio et al (2004) (Figure 1).

Table 1 Ethogram for behavioral analysis of pigs housed in facilities with different types of flooring.

\begin{tabular}{ll}
\hline \multicolumn{1}{c}{ Posture } \\
$\begin{array}{ll}\text { Seated } \\
\text { Lying }\end{array}$ & $\begin{array}{l}\text { On four legs } \\
\text { On two legs } \\
\text { Entire torso in contact with the ground }\end{array}$ \\
\hline \multicolumn{1}{c}{ Activities } \\
\hline Eating & With mouth in the feeder \\
Drinking & With mouth in the water fountain \\
Digging & $\begin{array}{l}\text { Animal exploring any part of the environment with } \\
\text { the snout }\end{array}$ \\
Interacting & Any interaction involving one or more animals \\
Walking & Moving \\
Idleness & Stationary, at rest and/or asleep \\
\hline Source: Adapted from Massari et al (2015)
\end{tabular}

These environmental data were used to calculate the black globe-humidity index (BGHI) for the evaluation of the thermal environment. According to Ponciano et al (2012), the BGHI is currently the most widely used index for the evaluation of animal thermal comfort in hot climate regions, such as Brazil. It incorporates Tdb, RH, Vair and radiation (in the form of Tbg) as a single value, calculated by means of Eq. 1 (Buffington et al 1981):

$$
\mathrm{BGHI}=\mathrm{Tbg}+0.36 \mathrm{Tdp}-330.08
$$

where $\mathrm{Tbg}=$ black globe temperature $(\mathrm{K})$ and $\mathrm{Tdp}=$ dew point temperature $(\mathrm{K})$.

In the statistical analysis, a scheme of subdivided plots was used for the thermal environment data ( $\mathrm{Tdb}, \mathrm{RH}, \mathrm{Tbg}$ and BGHI) in which the plots were composed of the different typologies of the installations and the subplots of the schedules, in a randomized complete block design (based on experimental days), with replicates being the days of collection. The data were submitted to an analysis of variance using an F-test and the means were compared using the Tukey test at 5\% significance, using the Sisvar program for statistical analysis.

Behavior variables were divided into two groups: posture (standing, lying and sitting) and behavioral patterns (drinking, eating, idling, walking and interacting). Statistical analyses were carried out by applying confidence intervals for the medians (95\%). Behavioral observations were converted to frequencies of the observed time using the Minitab statistical package, and these were then analyzed. 


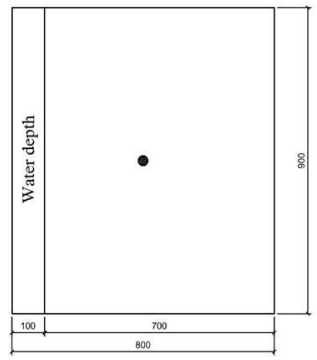

WDP

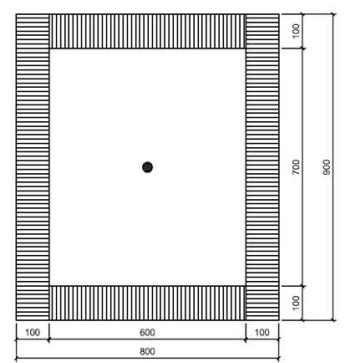

SLS
Figure 1 Floor plan of the pens (WDP: water depth, SLS: slotted floor on the sides).

\section{Results and Discussion}

The mean relative humidity showed a significant difference between the pens at 9 a.m, with the WDP pen having the highest mean value (77\%) (Table 2); this was as expected, due to the microclimate inside the pen created by the evaporation of the water in the indentation. In this context, Moreira et al (2003) show that the RH in the microclimates created in the installations directly influences the environmental conditions of the air; at other times, when the air is at a higher temperature, it has a greater capacity to absorb water vapor, and thus does not affect the relative humidity.

According to Muller (1989), for pigs weighing over 30 $\mathrm{kg}$ and in conditions of thermal comfort, the optimal $\mathrm{RH}$ is between $50 \%$ and $70 \%$. During the hours of observation, the mean RH was outside the range quoted by Muller only at 9 a.m. in the WDP, when a slightly higher value was recorded. The influence of $\mathrm{RH}$ on the reactions of the pigs is smaller than the direct effect caused by Tdb.

There was a significant difference for $\mathrm{Tdb}$ only at 9 a.m, with the SLS pen having the highest mean value $\left(20^{\circ} \mathrm{C}\right)$. The $\mathrm{Tdb}$ outside of the installations reached an absolute value of $31.9^{\circ} \mathrm{C}$ during the data collection phase (recorded in the afternoon). The average Tdb obtained in this study can be considered a thermoneutral temperature, since it is within the range recommended by Perdomo (1994) as the ideal temperature for the growth and termination phase of between $18^{\circ} \mathrm{C}$ and $26^{\circ} \mathrm{C}$.

No significant differences were observed in the globe temperature ( $\mathrm{Tbg}$ ) between the pens at any time.

Table 2 Mean values of environmental variables observed during the evaluation period, measured throughout the day, in swine growing and finishing facilities with floors with a water depth (WDP), and slotted sides (SLS).

\begin{tabular}{|c|c|c|c|c|}
\hline \multirow{2}{*}{ Variables $^{1}$} & \multirow[t]{2}{*}{ Pen } & \multicolumn{3}{|c|}{ Time } \\
\hline & & 9 a.m. & 12 p.m. & 3 p.m. \\
\hline \multirow{3}{*}{ RH (\%) } & WDP & $77^{\mathrm{a}}$ & $55^{\mathrm{a}}$ & $50^{\mathrm{a}}$ \\
\hline & SLS & $69^{b}$ & $52^{\mathrm{a}}$ & $47^{\mathrm{a}}$ \\
\hline & WDP & $20^{\mathrm{b}}$ & $25^{\mathrm{a}}$ & $26^{\mathrm{a}}$ \\
\hline \multirow[t]{2}{*}{$\mathrm{Tdb}\left({ }^{\circ} \mathrm{C}\right)$} & SLS & $20^{\mathrm{a}}$ & $25^{\mathrm{a}}$ & $26^{a}$ \\
\hline & WDP & $67^{\mathrm{a}}$ & $72^{\mathrm{a}}$ & $73^{\mathrm{a}}$ \\
\hline \multirow[t]{2}{*}{ BGHI } & SLS & $68^{a}$ & $72^{\mathrm{a}}$ & $73^{a}$ \\
\hline & WDP & $20^{\mathrm{a}}$ & $25^{\mathrm{a}}$ & $26^{\mathrm{a}}$ \\
\hline $\operatorname{Tbg}\left({ }^{\circ} \mathrm{C}\right)$ & SLS & $21^{\mathrm{a}}$ & $26^{\mathrm{a}}$ & $26^{\mathrm{a}}$ \\
\hline
\end{tabular}

${ }^{1}$ Relative air humidity (RH); black globe temperature (Tbg); dry bulb temperature (Tdb); black globe-humidity index (BGHI). Means followed by the same letter in the row do not differ in the Tukey test $(\mathrm{p}>0.05)$.

Although the BGHI did not show a significant difference between the facilities at the observed times, mean values at 3 p.m. were observed to be slightly above the value recommended by Tavares et al (2000) and Wolp (2010), who state that the upper limit condition of BGHI for growing and finishing pigs is 72 .

There was a difference $(\mathrm{P}<0.05)$ in mean air velocity between the pens only at 12 p.m. (Table 3 ).

The other schedules observed gave values without statistical differences. Although it is known that BGHI is indirectly affected by radiation and air velocity, the significant variation in ventilation was not sufficient in this case to cause differences in BGHI values (Table 2).

When assessing the behavioral data, it was observed that the animals remained standing more frequently in the WDP pen (Figure 2), possibly due to the influence of the environmental enrichment caused by the presence of the water depth. Consequently, observations of the lying position also differed statistically, and this was observed more frequently in the SLS pen, where the pigs spent most of the time lying down, this result is in agreement with behavioral studies of pigs carried out by Kiefer et al (2010) with animals kept in thermal 
comfort $\left(21^{\circ} \mathrm{C}\right)$, these authors found a percentage higher than $82 \%$ of the time evaluated.

The sitting behavior did not differ statistically between treatments. The mean values found in the present study are close to those observed by Dalla Costa et al (2009), who found animals sitting $4.42 \%$ of the time in slaughterhouse waiting pens. According to Hötzel et al (2007), this sitting behavior can be used as a parameter to estimate pig welfare, and a reduction in its frequency can indicate impairment of welfare.

Table 3 Average values of air velocity (Vair, $\mathrm{m} \mathrm{s}^{-1}$ ) in sheds for growing and finishing swine with different types of pens

\begin{tabular}{lccc}
\hline $\begin{array}{l}\text { Treatments } \\
(\text { Pens })\end{array}$ & & Time \\
\hline & 9 a.m. & 12 p.m. & 3 p.m. \\
WPP & $0.26^{\mathrm{a}}$ & $0.30^{\mathrm{b}}$ & $0.20^{\mathrm{a}}$ \\
SLS & $0.40^{\mathrm{a}}$ & $0.69^{\mathrm{a}}$ & $0.43^{\mathrm{a}}$ \\
\hline
\end{tabular}

Pens: water depth (WDP), partially slotted floors at the sides (SLS). Air velocity (Vair). Means followed by the same letter within one column do not differ significantly in Tukey's test.
The mean time spent by the pigs on each activity was not statistically different between the pens for any of the activities analyzed (Figure 3 ).

Digging behavior is strongly related to eating behavior; it was observed by Massari et al (2015) that domestic pigs exploit the environment in search of food. However, Stevenson (2000) found that under natural breeding conditions, pigs spent about $75 \%$ of their time in activities such as digging, searching for food and exploring the environment; confinement in highly stocked bins without environmental enrichment makes it impossible to perform these behaviors.

Ieler et al (2009), who worked with pigs housed in facilities with overlapping beds, mention that exploratory behavior is associated with the habit of vigorously fouling the soil, and that this behavior may be a stress factor for animals housed in installations with cement floors, since there is no possibility of movement as in the superimposed bed.

According to the results of Debreceni et al (2014), normal eating behavior has an average frequency of $16 \%$. This value is slightly higher than the frequencies observed in the present study, which was $13.33 \%$ in both pens.

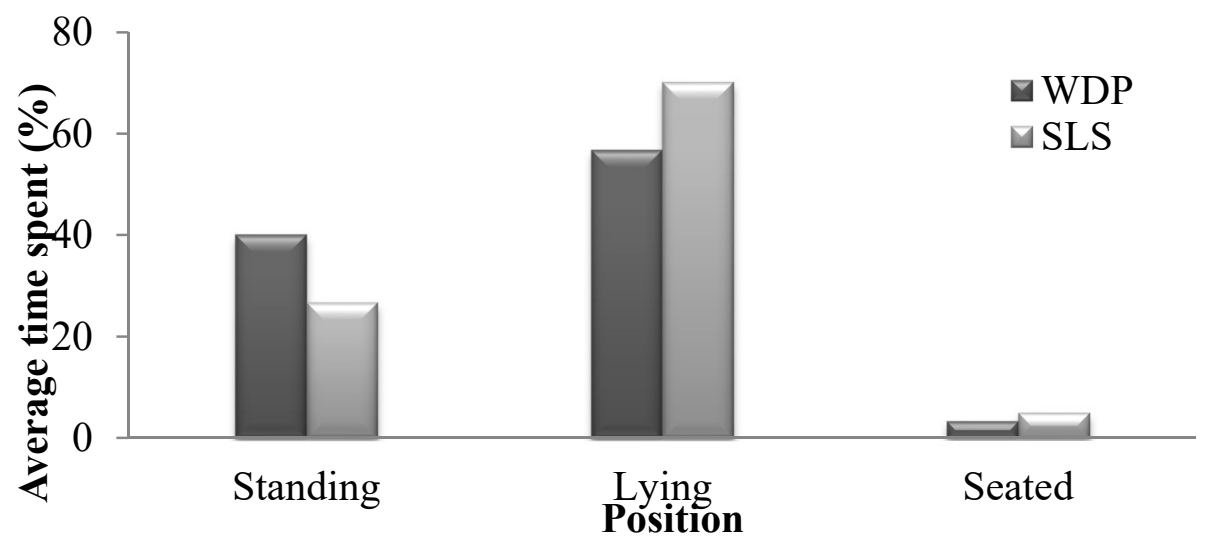

Figure 2 Average time spent (\%) per pig (growth/termination) in each behavior (Pens: water depth (WDP), partially slotted floors at the sides. (SLS)).

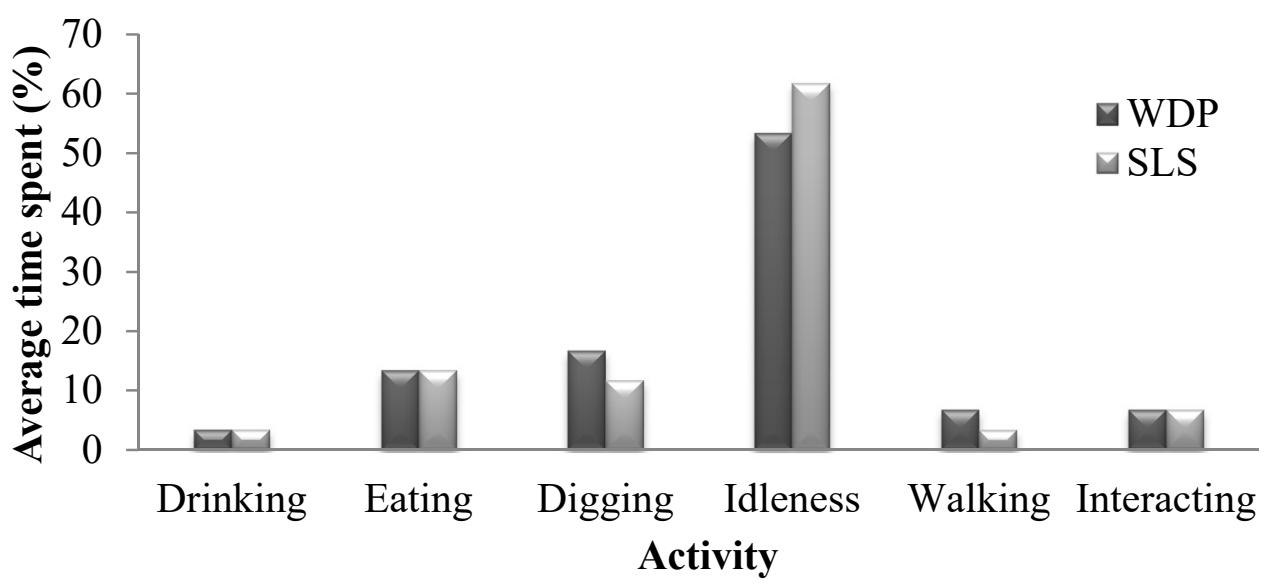

Figure 3 - Average time spent (\%) per pig (growth / termination) in each behavior (Pens: water depth (WDP), partially slotted floors at the sides (SLS)). 
No statistical difference was observed in the idling behavior (Figure 3), which was more frequent than the other behaviors; the mean frequencies were 53\% for WDP and $62 \%$ for SLS. According to Broom and Fraser (2010), idleness is characterized by the sum of resting and sleeping behaviors, and is important, since it has the function of energy conservation. These authors also mention that when confined, pigs are more likely than other farmed animals to spend time resting and sleeping.

Ferreira et al. (2015) studied the behavior of growing pigs in relation to lighting conditions their results corroborate those of the present study, since they found that idling was more frequent in comparison with other behaviors, with an average of $87.64 \%$ of the time (corresponding to 21.03 hours per day) spent in this way. The present study found lower mean values (5.33 hours/day for WDP, and 6.16 hours/day for SLS). This difference may arise from the differences between the experimental conditions, such as the observation time used; the present study took into account only the diurnal period, and thus involved fewer hours.

\section{Conclusions}

Although the pens showed differences in terms of the dry bulb temperature, this temperature can be considered thermoneutral for creation in the growth and termination phase. Animals housed in the WDP pen remained standing for longer, possibly due to the environmental enrichment caused by the presence of the water depth.

\section{References}

Anil L, Anil SS, Deen J (2002) Relationship between postural behavior and gestation stall dimensions in relation to sow size. Applied Animal Behavior Science 77:173-181.

Buffington DE, Collazo-Arocho A, Canton GH, Pitt D, Thatcher WW, Collier RJ (1981) Black globe-humidity index (BGHI) as comfort equation for dairy cows. Transactions of the ASAE 24:711714.

Broom DM, Fraser AF (2010) Comportamento e bem-estar de animais domésticos. Manole, $4^{\mathrm{a}}$ edição, 452p.

Dalla Costa OA, Ludke JV, Costa MJRP, Pelosso JV, Coldebella A, Triques N (2009) Efeito do jejum na granja e condições de transporte sobre o comportamento dos suínos de abate nas baias de descanso e lesões na pele. Ciência Animal Brasileira 10:48-58.

Debreceni O, Lehotayová A, Bučko O, \& Petrák, J (2014) The Behaviour of the Pigs Housed in Hot Climatic Conditions. Journal of Central European Agriculture 15:64-75.

Ferreira RA, Fassani EJ, Ribeiro BPVB, Oliveira RF, Cantarelli VS, Abreu MLT (2015) Programas de luz para suínos em crescimento. Archives of Veterinary Science 20:65-70.

Hötzel MJ, Souza GP, Machado Filho LCP, Irgang R, Probst R (2007) Estresse e reconhecimento de seres humanos em leitões recém desmamados. Revista Biotemas 4:91-98.

Huynh TTT, Arnink AJA, Gerrits WJJ, Heetkamp MJH, Canh TT, Spoolder HAM, Kemp B, Verstegen MWA (2005) Thermal behavior of growing pigs in response to high temperature and humidity. Applied Animal Behaviour Science 91:1-16.

Ieler J, Linzmeyer DAJ, Baade ES, Civiero PAG (2009) Comportamento e crescimento de suínos recém-desmamados em cama sobreposta. In: Feira de conhecimento tecnológico e científico, 10., 2009, Rio do Sul. Anais... Rio do Sul: Instituto Federal de Educação, Ciência e Tecnologia Catarinense Campus Rio do Sul, 2009.

Kiefer C, Meignen BCG, Sanches JF, Carrijo AS (2009) Resposta de suínos em crescimento mantidos em diferentes temperaturas' Archivos de Zootecnia 58:55-64.

Kiefer C, De Moura MS, Da Silva EA, Dos Santos AP, Silva CM, Da Luz MF, Nantes CL (2010) Respostas de suínos em terminação mantidos em diferentes ambientes térmicos. Revista Brasileira de Saúde e Produção Animal 11:496-504.

Kittawornrat A, Zimmerman, JJ (2011) Toward a better understanding of pig behavior and pig welfare. Animal Health Research Reviews 12:25-32.

Machado Filho LCP, \& Hotzel MJ (2000) Bem-estar dos suínos. In: Seminário Internacional de Suinocultura, 5., 2000, São Paulo- SP. Anais. Concórdia: Embrapa Suínos e Aves, p. 70-83.

Maia APA, Sarubbi J, Medeiros BBL, Moura DJ (2013) Enriquecimento ambiental como medida para o bem-estar positivo de suínos. Revista do Centro do Ciências Naturais e Exatas 14:28622877.

Massari JM, Curi TMRC, Moura DJ, Medeiros BBL, Salgados DD (2015) Características comportamentais de suínos em crescimento e terminação em sistema "wean to finish". Engenharia Agrícola 35:646-656.

Ponciano PF, Yanagi Junior T, Ferraz GAS, Schiassi L, \& Campos AT (2012) Spatial variability of enthalpy in broiler house during the heating phase. Revista Brasileira de Engenharia Agrícola e Ambiental 20:570-575.

Stevenson P (2000) Questões de bem-estar animal na criação intensiva de suínos na União Européia. Em: I conferência virtual internacional sobre qualidade de carne suína. Anais. Concórdia. Embrapa Suínos e Aves. 253 p. Documento 69.

Tavares SLS, Oliveira RFM, Donzele JL (2000) Influência da temperatura ambiente sobre o desenvolvimento e os parâmetros fisiplógicos de suínos machos cadastrados dos 30 aos $60 \mathrm{~kg}$. Revista Brasileira de Zootecnia 29:99-205.

Veloni ML, Prado PL, Arssuffi BM, Ballestero MCM, Oliveira MG, Abreu PB, Oliveira LG (2013) Bem-estar animal aplicado nas criações de suínos e suas implicações na saúde dos rebanhos. Revista Científica de Medicina Veterinária 21:1-21.

Wolp RC (2010) Suínos em crescimento mantidos em ambiente de alta temperatura alimentados com dietas contendo diferentes níveis de óleo e proteína bruta. Dissertação de mestrado (Zootecnia). Universidade Federal de Lavras - MG. 68p. 